CZU: 338.43: 634.8(478) -29

https://doi.org/10.52507/2345-1106.2021-2.22

АНАЛИЗ СОСТОЯНИЯ ВОЗДЕЛЫВАНИЯ ВИНОГРАДА В АТО ГАГАУЗИЯ

ПАРМАКЛИ Дмитрий, доктор хабилитат экономических наук, профессор, Комратский государственный университет https://orcid.org/0000-0003-2002-6104

КАРА Сергей, доктор сельскохозяйственных наук, конференциар, Комратский государственный университет, kara_sergey@mail.ru https://orcid.org/0000-0002-0556-3625 


\begin{abstract}
АННОТАЦИЯ
В данной работе показаны роль и значение виноградарства для экономики региона. Представлено состояние производства винограда в АТО Гагаузия за 1997-2020 годы и анализ устойчивости производства за эти годы с использованием метода среднегодовых скользящих показателей. Обоснованы потенциальные уровни урожайности виноградных лоз и оценены реальные резервы роста урожайности виноградников. Также был проведен анализ показателей производства винограда в сельскохозяйственных предприятиях Комратского, Чадыр-Лунгинского и Вулканештского районов за 2009-2020 годы. В ходе анализа были произведены расчеты темпов прироста (спада) посевных площадей, валового сбора и урожайности за исследуемые 24 года. Кроме того, был рассчитан прогноз показателей на 2021-2022 годы. Все рассчитанные показатели представлены на графиках для наглядности. В заключение следует отметить, что предложенный вариант анализа состояния выращивания винограда в АТО Гагаузия достаточно прост и доступен, поэтому может использоваться как практикующими специалистами, так и студентами вузов.
\end{abstract}

Ключевье слова: виноградарство, анализ, урожайность, валовой сбор, стабильность, потенциал, прогноз.

\title{
ANALYSIS OF THE STATE OF GRAPE CULTIVATION IN ATU GAGAUZIA
}

PARMAKLI Dmitry,

Doctor habilitat of economic sciences, Professor, Comrat State University https://orcid.org/0000-0003-2002-6104

\author{
KARA Sergei, \\ Doctor of Agricultural Sciences, Associate Professor, \\ Comrat State University, \\ kara_sergey@mail.ru \\ https://orcid.org/0000-0002-0556-3625
}

\begin{abstract}
SUMMARY
The role and importance of viticulture for the regional economy are shown. The state of grape production in ATU Gagauzia for 1997-2020 and an analysis of the stability of production for these years are presented, using the method of average annual moving indicators. Potential levels of vine productivity have been substantiated and real reserves for growth of vineyards productivity have been estimated. The analysis of indicators of grape production in agricultural enterprises of Comrat, Ceadir-Lunga and Vulcanesti districts for 2009-2020 was also carried out. In the course of the analysis, calculations were made of the growth (fall) rates of the harvesting areas, gross harvest and yield for the studied 24 years. In addition, the forecast of indicators for 2021-2022 was calculated. All calculated indicators are presented in the graphs for clarity. In conclusion, it is noted that the proposed version of the analysis of the state of grape cultivation in ATU Gagauzia is quite simple and affordable and therefore can be used by both practicing specialists and university
\end{abstract} students.

Key words: viticulture, analysis, productivity, gross yield, stability, potential, forecast.

Введение. Виноградарство в АТО Гагаузия является наиболее интенсивной отраслью в сельскохозяйственном производстве. Интенсификация данной отрасли - это последовательное совершенствование технологии, техники и организации производства, внедрение в производство высокопродуктивных сортов, клонов, достижений науки и передового опыта [1, с. 36]. Анализ состояния возделывания винограда в автономии позволяет выяснить уровень его развития, вскрыть имеющиеся недостатки и определить пути развития.

Актуальность темы подтверждается тем, что анализ состояния возделывания винограда на предприятии или регионе осуществляется различными методами, и выбор среди них наиболее оптимального варианта не всегда представляется очевидным. Предложенный нами подход анализа представляется достаточно полным и вполне доступным для широкого использования на практике.

Цель исследования - предложить методику проведения анализа состояния возделывания винограда в регионе и обосновать современный подход его проведения, подтвердив его особенности на конкретных примерах из практики.

Методологическая основа исследования. В ходе исследования были использованы экономикостатистический и графический методы. Они позволили в полной мере достигнуть цель исследования.

Результаты.

Состояние производства винограда в АТО Гагаузия за 1997-2020 годы.

Настоящее исследование охватывает период возделывания традиционной культуры автономии за 1997-2020 годы, т.е. последние 24 года. Сложившиеся показатели производства за этот период представлены в таблице 1. 
Таблица 1. Показатели возделывания винограда в хозяйствах всех категорий АТО Гагаузия за 1997-2020 годы

\begin{tabular}{|c|c|c|c|}
\hline Год & Площадь. га & Валовой сбор, т & Урожайность, ц/га \\
\hline 1997 & 16816 & 37089 & 22,1 \\
\hline 1998 & 15685 & 29838 & 19 \\
\hline 1999 & 14914 & 31535 & 21,1 \\
\hline 2000 & 12653 & 53000 & 41,9 \\
\hline 2001 & 12459 & 33539 & 26,9 \\
\hline 2002 & 12265 & 46668 & 38 \\
\hline 2003 & 11911 & 44909 & 37,7 \\
\hline 2004 & 12573 & 57402 & 45,7 \\
\hline 2005 & 12284 & 40249 & 32,8 \\
\hline 2006 & 12201 & 29480 & 24,2 \\
\hline 2007 & 11739 & 24320 & 20,7 \\
\hline 2008 & 9187 & 31958 & 34,8 \\
\hline 2009 & 8226 & 26567 & 32,3 \\
\hline 2010 & 8242 & 13961 & 16,9 \\
\hline 2011 & 5852 & 25173 & 42,2 \\
\hline 2012 & 5874 & 21329 & 36,2 \\
\hline 2013 & 4841 & 36714 & 85,8 \\
\hline 2014 & 4820 & 32095 & 66,6 \\
\hline 2015 & 4876 & 28582 & 58,6 \\
\hline 2016 & 4943 & 33577 & 67,7 \\
\hline 2017 & 4900 & 39162 & 79,9 \\
\hline 2018 & 4841 & 53715 & 92,7 \\
\hline 2019 & 6622 & 44847 & 67,7 \\
\hline 2020 & 4491 & 21999 & 49,0 \\
\hline
\end{tabular}

Источник: данные главного управления сельского хозяйства АТО Гагаузия

Краткий анализ динамики показателей возделывания винограда показывает, что с 1997 по 2020 год отмечается тенденция заметного роста урожайности (рис.1). Как свидетельствует уравнение тренда $(\mathrm{y}=2,307 \mathrm{x}+15.34)$ в среднем за год рост продуктивности виноградных насаждений составил 2,307 ц/га. При этом отмечается тенденция снижения валового сбора винограда (рис.2). В соответствии с уравнением тренда $(\mathrm{y}=-259.9 \mathrm{x}+$ 38154) каждый год сбор продукции снижался «со скоростью» 259,9 т. Это объясняется убывающей тенденцией плодоносящих площадей (рис.3) в среднем за год на 539,7 га ( $\mathrm{y}=-539,7 \mathrm{x}+16048)$.

Графическое представление динамики урожайности пшеницы за исследуемый период позволяет отметить, что в соответствии с полиномиальным трендом $(\mathrm{y}=0,086 \mathrm{x} 2+0,141 \mathrm{x}+$
24,73) сбор янтарных гроздей с единицы площади имел тенденцию роста, особенно во второй период (рис.1).

Если разделим период исследования на 2 равные части, то за 1997-2008 годы среднегодовая урожайность винограда составила 27,6 ц/га, а за 2009-2020 годы- лишь 26,4 ц/га (табл.1).

Более детальное обследование показывает, что с 1997 по 2008 годы наблюдается снижение урожайности (рис.4) в соответствии с уравнением тренда $(\mathrm{y}=-0,727 \mathrm{x}+31,33)$ в среднем за год на 0,727 ц/га, а с 2009 по 2020 годы был отмечен ежегодный прирост $(\mathrm{y}=0,696 \mathrm{x}+21,15)$ продуктивности полей почти 0,7 ц/га (рис.5). Тем не менее уровень продуктивности полей во втором периоде оказался ниже чем в первом на 1,2 ц/га $(27,6-26,4)$. 


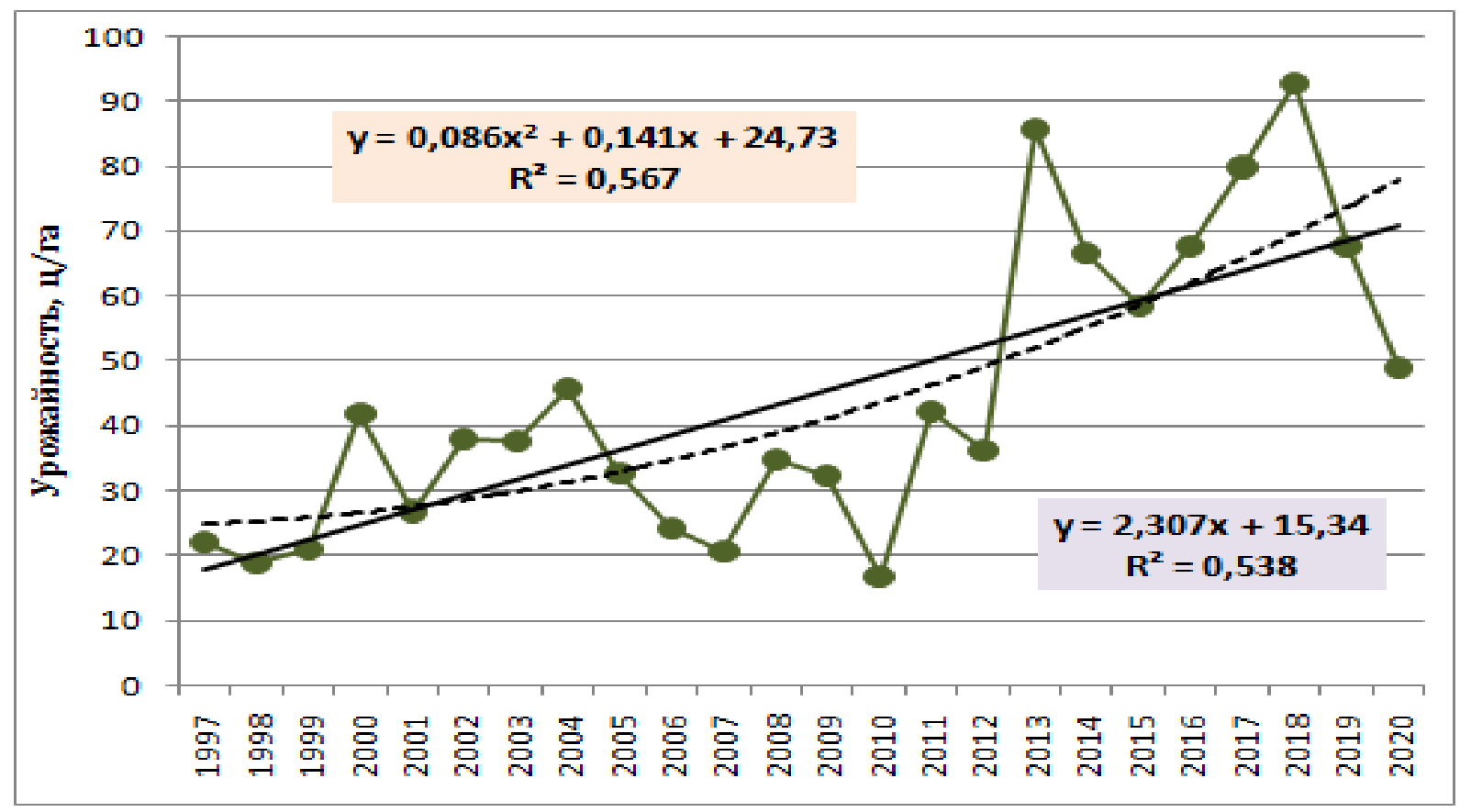

Рис.1. Динамика урожайности винограда в АТО Гагаузия за 1997-2020 годы

Источник: составлено по данным таблиць 1

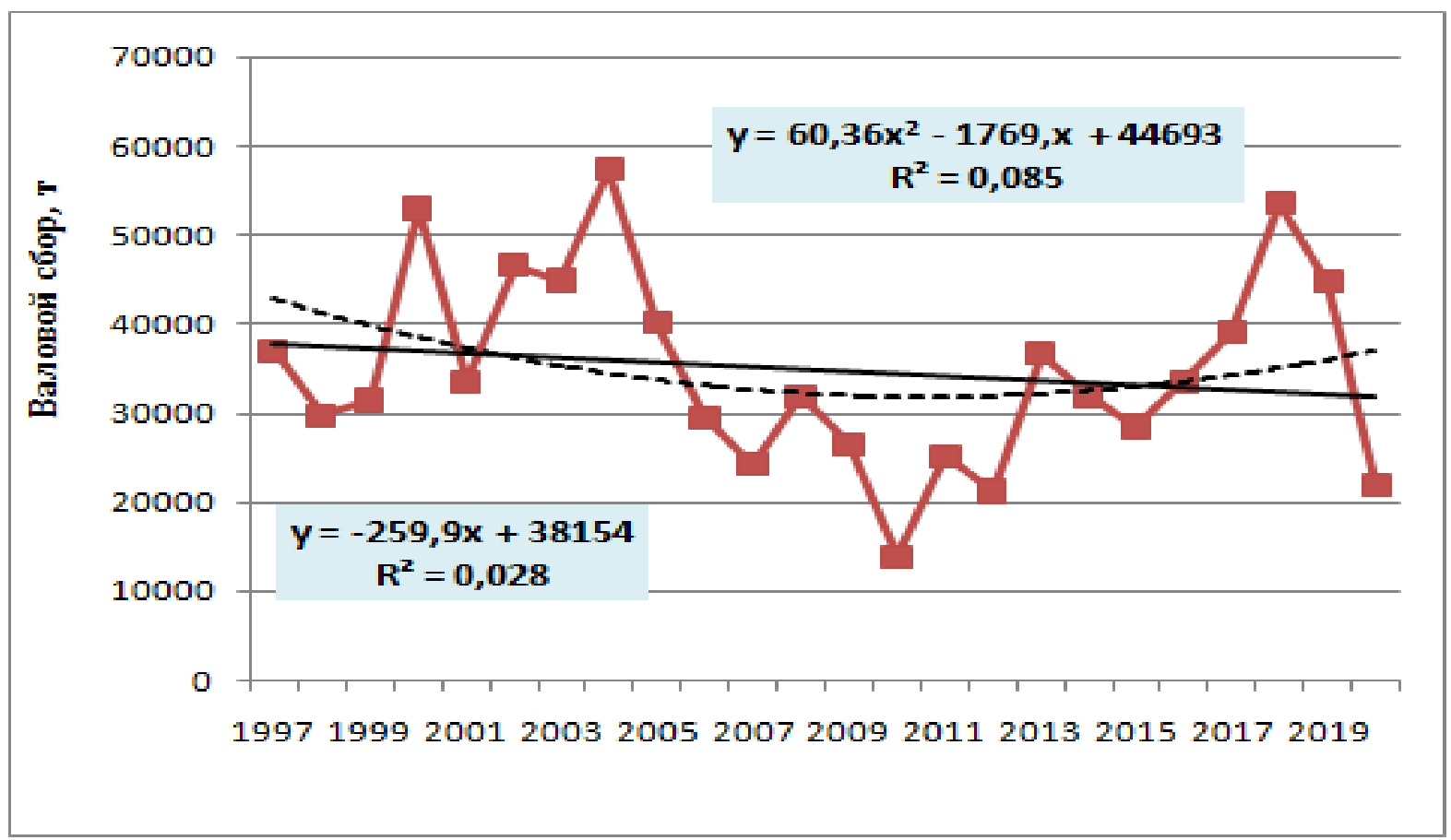

Рис.2. Динамика валового сбора винограда в АТО Гагаузия за 1997-2020 годы

Источник: составлено по данным таблицы 1 


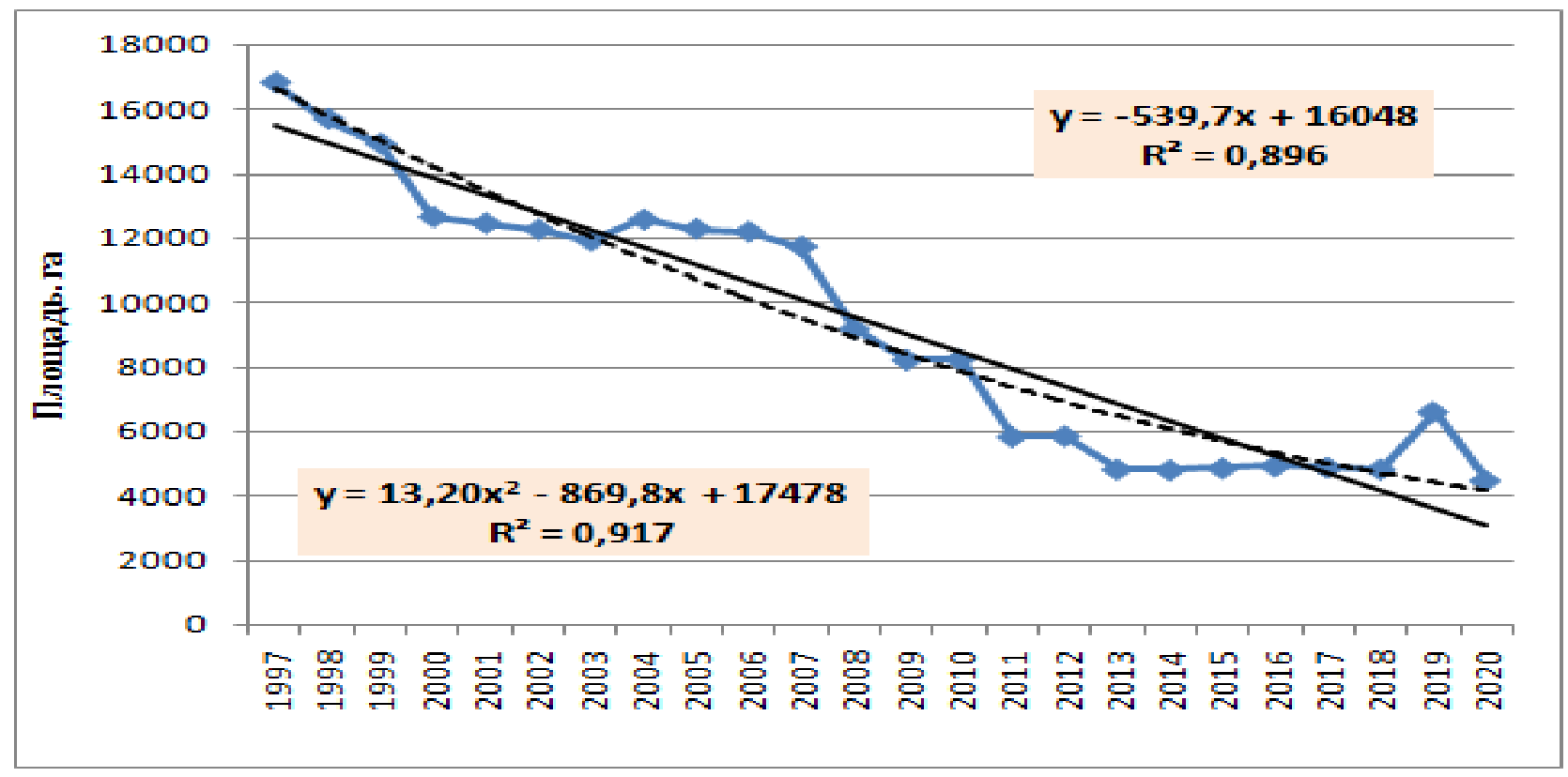

Рис.3. Динамика плодоносящей площади виноградников в АТО Гагаузия а 1997-2020 годы

Источник: составлено по данным таблицы 1

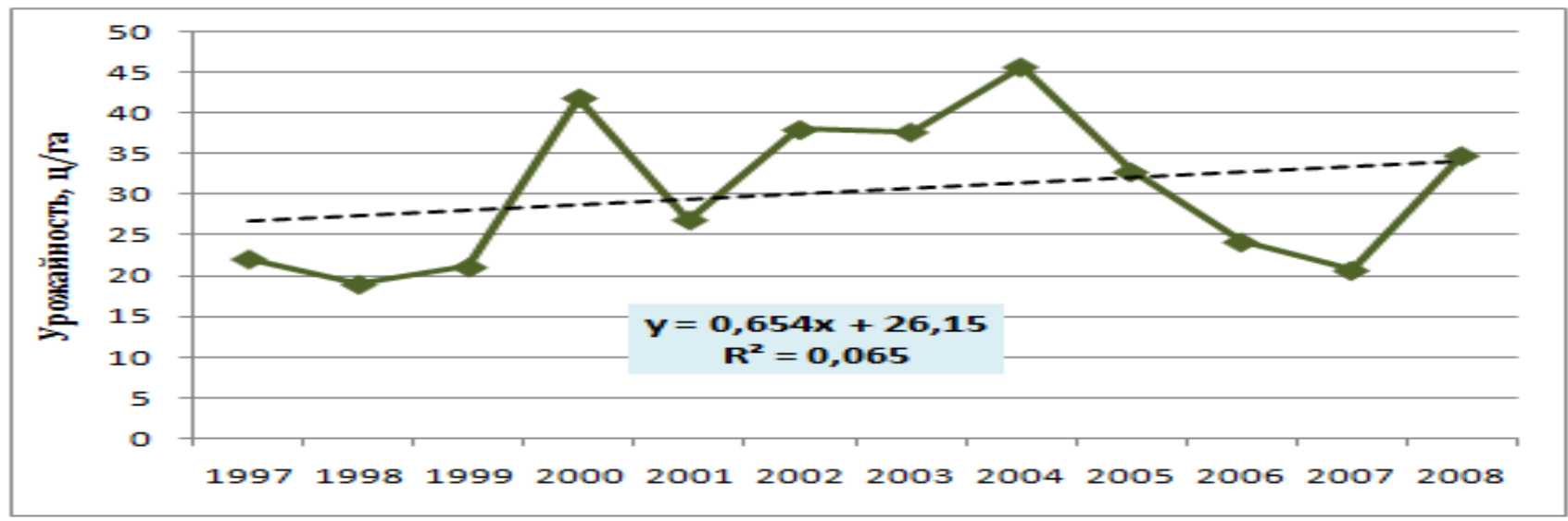

Рис.4. Динамика урожайности винограда в АТО Гагаузия за 1997-2008 годы

Источник: составлено по данным таблицьы 1

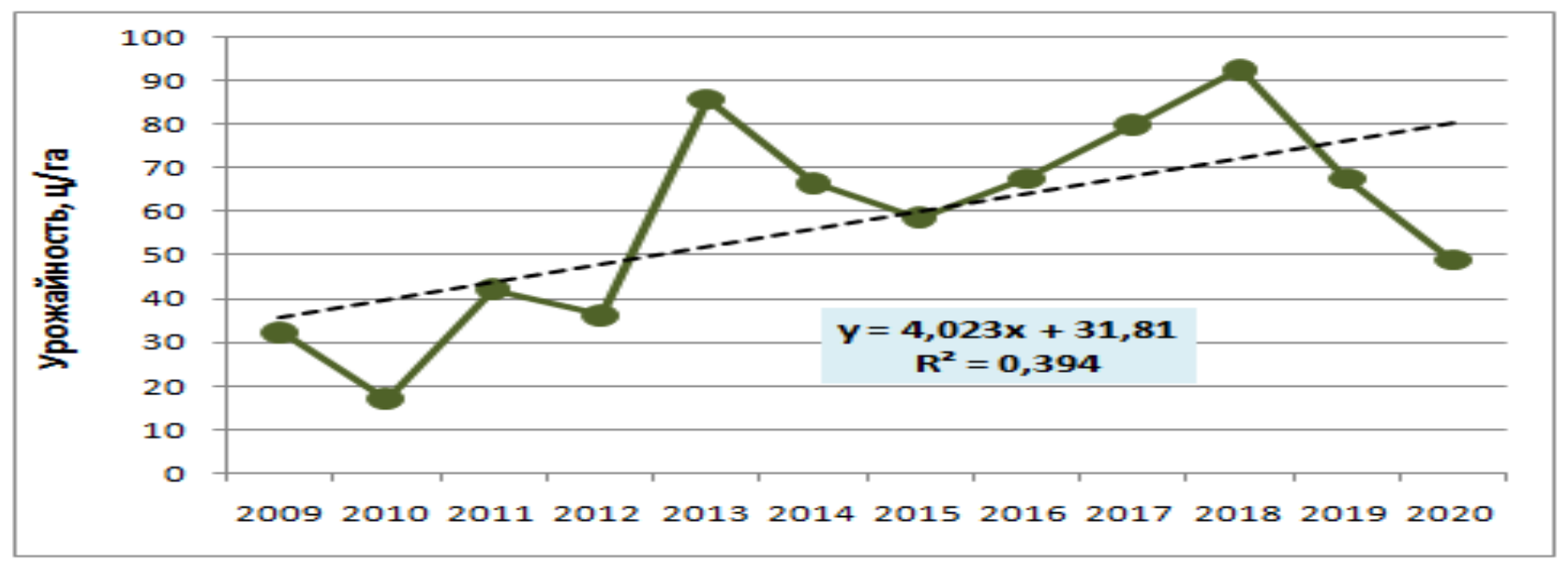

Рис.5. Динамика урожайности винограда в АТО Гагаузия за 2009 - 2020 годы

Источник: составлено по данным таблицы 1 


\section{Обоснование потенциальных уровней урожсайности}

Под производственным потенциалом земельных ресурсов следует понимать максимально возможный выход продукции по качеству и количеству в условиях наиболее эффективного использования всех имеющихся средств производства и труда. Потенциальные показатели выхода продукции с единицы площади за определенный период, рекомендуется рассчитывать по формуле [2, с. 183 184]:

$$
\text { qпот }=\sqrt[\kappa]{\Pi}, \text { ц/га }
$$

где: $\kappa=\sqrt{\mathrm{T}}(\mathrm{T}-$ число лет в анализируемом периоде);

П - произведение наивысших показателей урожайности за «к» лет.

При определении показателя «к», следует полученные расчетные величины округлять до целой величины. В нашем примере из анализируемых 24 года в расчет принимаем показатели 5 лет $(\kappa=\sqrt{24}=$
$4,9 \approx 5)$.

Потенциал продуктивности земли при производстве винограда формируется на базе показателей урожайности за 2013, 2016, 2017, 2018 и 2019 годы:

$$
\begin{gathered}
\text { qпот }=\sqrt[5]{85,8 \cdot 67,7 \cdot 79,9 \cdot 92,7 \cdot 67,7}= \\
78,1 \text { ц/га }
\end{gathered}
$$

Таким образом, фактический среднегодовой показатель урожайности ниже потенциального на 40,6 ц/га $(78,1$ - 37,5). Следовательно, данный показатель можно считать реальным резервом наращивания продуктивности виноградных насаждений. Другими словами, потенциальный уровень продуктивности земли при производстве винограда освоен в сельском хозяйстве АТО Гагаузия на 48,0\% $(37,5 * 100 / 78,1)$. Сложившийся фактический уровень урожайности пшеницы за исследуемые 1997-2020 годы и резерв наращивания, а также удельный вес освоения потенциального показателя наглядно представлены на графике (рис.6).

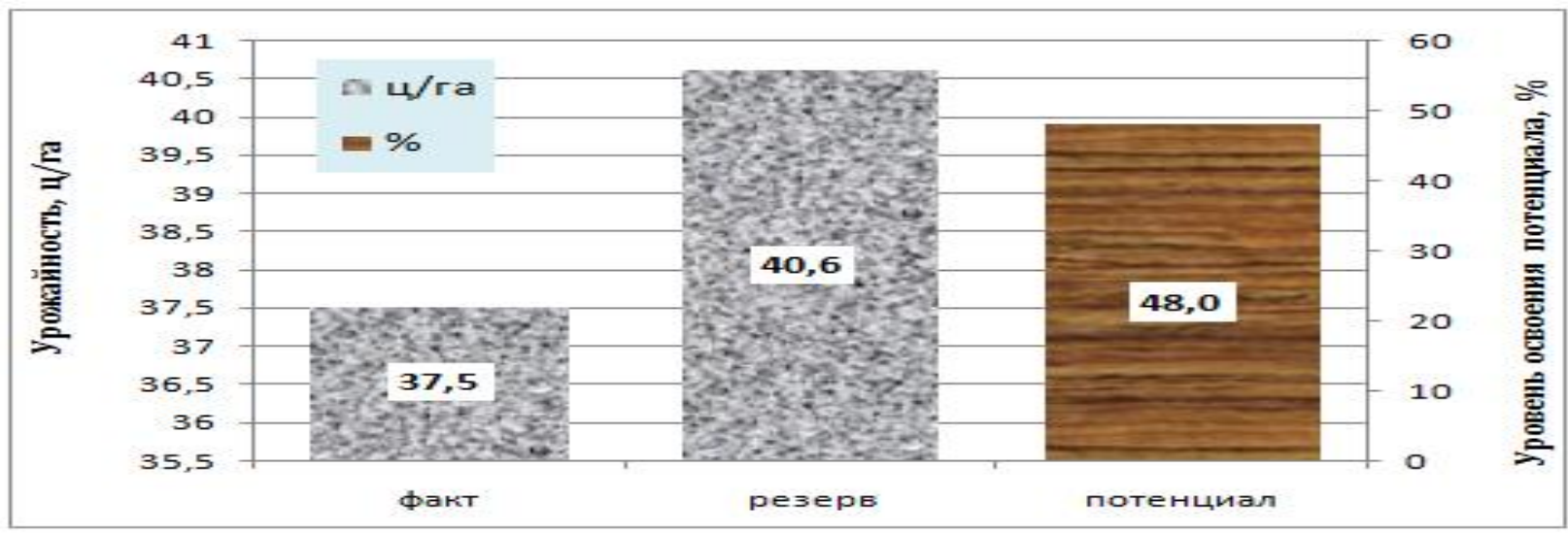

Рис.6. Показатели фактической урожайности винограда, резервы его роста и уровень освоения потенциала в АТО Гагаузия за 1997-2020 годы

Источник: расчеты авторов

Более объективное значение потенциальных значений урожайности винограда для сельскохозяйственных предприятий можно получить при учете реальных условий региона возделывания культуры. Вот почему важно дифференцировать показатели продуктивности земли в разрезе районов.

Анализ показатели производства винограда в сельскохозяйственных предприятиях Комратского, Чадыр-Лунгского и Вулканештского районов за 2009-2020 годы. Рассмотрим сложившиеся показатели урожайности винограда в Комратском, Чадыр-Лунгском и Вулканештском районах за 2009-2020 годы. Они представлены в таблице 2.

Определим показатели потенциальной урожайности в районах автономии с учетом сложившихся значений за последние 12 лет. В данном примере из анализируемых 12 лет в расчет принимаем показатели 3 лет ( $к=\sqrt{12}=3,46 \approx 3$ ).
Потенциал продуктивности земли при производстве винограда формируется на базе показателей урожайности:

в Комратском районе за 2017, 2018 и 2019 годы:

$$
\text { qпот }=\sqrt[3]{78,5 \cdot 95,3 \cdot 92,4}=88,4 \text { ц/га }
$$

в Чадыр-Лунгском районе за 2013, 2017 и 2018 годы:

$$
\text { qпот }=\sqrt[3]{67,1 \cdot 74,4 \cdot 90,0}=76,6 \text { ц/га }
$$

в Вулканештском районе за 2013, 2017 и 2018 годы:

$$
\text { qпот }=\sqrt[3]{92,1 \cdot 86,3 \cdot 90,2}=89,5 \text { ц/га }
$$


в АТО Гагаузия за 2013, 2017и 2018 годы:

qпот $=\sqrt[3]{75,8 \cdot 79,9 \cdot 92,7}=82,5$ ц/га

Таблица 2. Показатели производства пшеницы в сельскохозяйственных предприятиях Комратского, Чадыр-Лунгского и Вулканештского районов за 2009-2020 годы

\begin{tabular}{|c|c|c|c|c|}
\hline Год & Наименование района & Площадь уборки, га & $\begin{array}{l}\text { Валовой } \\
\text { сбор, т }\end{array}$ & $\begin{array}{l}\text { Урожайность, } \\
\text { ц/га }\end{array}$ \\
\hline 2009 & Комратский & 4348 & 13920 & 32,0 \\
\hline 2010 & & 5334 & 8425 & 15,8 \\
\hline 2011 & & 3579 & 14468 & 40,4 \\
\hline 2012 & & 3412 & 10808 & 31,7 \\
\hline 2013 & & 2492 & 17387 & 69,8 \\
\hline 2014 & & 2587 & 16844 & 65,1 \\
\hline 2015 & & 2592 & 18441 & 71,1 \\
\hline 2016 & & 2472 & 16848 & 68,2 \\
\hline 2017 & & 2399 & 18826 & 78,5 \\
\hline 2018 & & 2412 & 31502 & 95,3 \\
\hline 2019 & & 2634 & 24333 & 92,4 \\
\hline 2020 & & 2644 & 14247 & 53,9 \\
\hline В среднем & & 3075 & 17171 & 55,8 \\
\hline 2009 & Чадыр-Лунгский & 2513 & 6502 & 25,9 \\
\hline 2010 & & 1585 & 1607 & 10,1 \\
\hline 2011 & & 934 & 2762 & 29,6 \\
\hline 2012 & & 953 & 3290 & 34,5 \\
\hline 2013 & & 920 & 6171 & 67,1 \\
\hline 2014 & & 777 & 5169 & 66,5 \\
\hline 2015 & & 1114 & 5199 & 46,7 \\
\hline 2016 & & 1004 & 5260 & 52,4 \\
\hline 2017 & & 1053 & 7835 & 74,4 \\
\hline 2018 & & 1002 & 9018 & 90,0 \\
\hline 2019 & & 1757 & 6258 & 35,6 \\
\hline 2020 & & 544 & 2452 & 45,1 \\
\hline В среднем & & 1180 & 5127 & 43,5 \\
\hline 2009 & Вулканештский & 1365 & 6145 & 45,0 \\
\hline 2010 & & 1323 & 3883 & 29,3 \\
\hline 2011 & & 1339 & 7445 & 55,6 \\
\hline 2012 & & 1509 & 7232 & 47,9 \\
\hline 2013 & & 1429 & 13157 & 92,1 \\
\hline 2014 & & 1457 & 10082 & 69,2 \\
\hline 2015 & & 1170 & 4942 & 42,2 \\
\hline 2016 & & 1467 & 11469 & 78,2 \\
\hline 2017 & & 1448 & 12501 & 86,3 \\
\hline 2018 & & 1427 & 13196 & 90,2 \\
\hline 2019 & & 2231 & 14256 & 63,9 \\
\hline 2020 & & 1303 & 5321 & 40,7 \\
\hline В среднем & & 1456 & 9136 & 62,8 \\
\hline 2009 & ATO Гагаузия & 8226 & 26567 & 32,3 \\
\hline 2010 & & 8242 & 13915 & 16,9 \\
\hline 2011 & & 5852 & 24675 & 42,2 \\
\hline 2012 & & 5875 & 21329 & 36,3 \\
\hline 2013 & & 4841 & 36715 & 75,8 \\
\hline 2014 & & 4821 & 32095 & 66,6 \\
\hline 2015 & & 4876 & 28582 & 58,6 \\
\hline 2016 & & 4943 & 33577 & 67,7 \\
\hline 2017 & & 4900 & 39162 & 79,9 \\
\hline 2018 & & 4841 & 53715 & 92,7 \\
\hline 2019 & & 6622 & 44847 & 67,7 \\
\hline 2020 & & 4491 & 21999 & 49,0 \\
\hline В среднем & & 5711 & 31432 & 55,0 \\
\hline
\end{tabular}

Источник: данные главного управления сельского хозяйства АТО Гагаузия 
Как показывают расчеты производство винограда в Комратском районе достигло за исследуемый период 54,6\% всего объема автономии, в ЧадырЛунгском и Вулканештском соответственно 13,6\% и 29,1\%. Наивысшая продуктивность земли была достигнута в сельскохозяйственных предприятиях Комратского района. Здесь каждый гектар плодоносящих насаждений обеспечил выход гроздей в объеме 62,8 ц., что выше чем в Комратском и Чадыр-Лунгском районах соответственно на 7,0 и 19,3 ц.

Потенциальный уровень продуктивности земельных ресурсов определяется как сумма фактической урожайности (qф) и реального резерва ее роста $(\Delta q)[3$, с. 234$]$ :

$$
\mathbf{q \Pi о T}=\mathbf{q \phi}+\Delta q
$$

Наличие показателей потенциальной и фактической урожайности возделываемых культур позволяет землепользователям выявлять имеющиеся резервы повышения продуктивности земли и на этой основе принимать меры по наращиванию объемов валовых сборов продукции. Величины резервов урожайности наглядно представлены на рисунке 7.

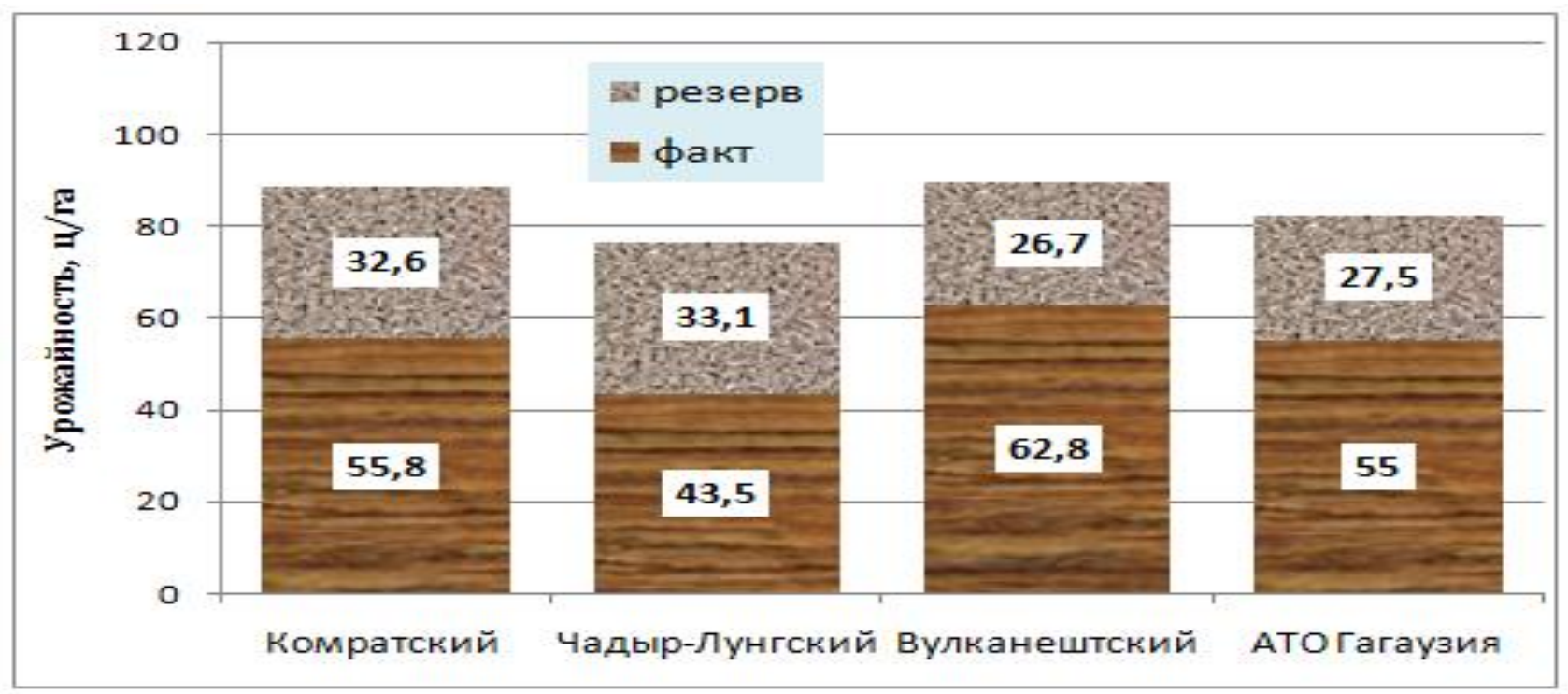

Рис.7. Показатели урожайности винограда и резервы его роста в Комратском, Чадыр-Лунгском и Вулканештском районах в среднем за 2009-2020 годы.

Источник: выполнено по данным таблицы 2

Нельзя не отметить существенное наращивание продуктивности земли в автономии за последние 5 лет. Несмотря на неблагоприятные погодноклиматические условия 2020 года, в Комратском, Чадыр-Лунгском и Вулканештском районах урожайность винограда достигла соответственно
84,$2 ; \quad 57,5$ и 72,0 ц/га, что выше, чем за предшествующие 7 лет соответственно на 43,0 ц/га или на $51,1 \%$, на 22,6 ц/га или на $39,3 \%$ и на 16,9 ц/га или на 23,5\%. Сравнительные показатели урожайности за указанные годы представлены на графике (рис.8).

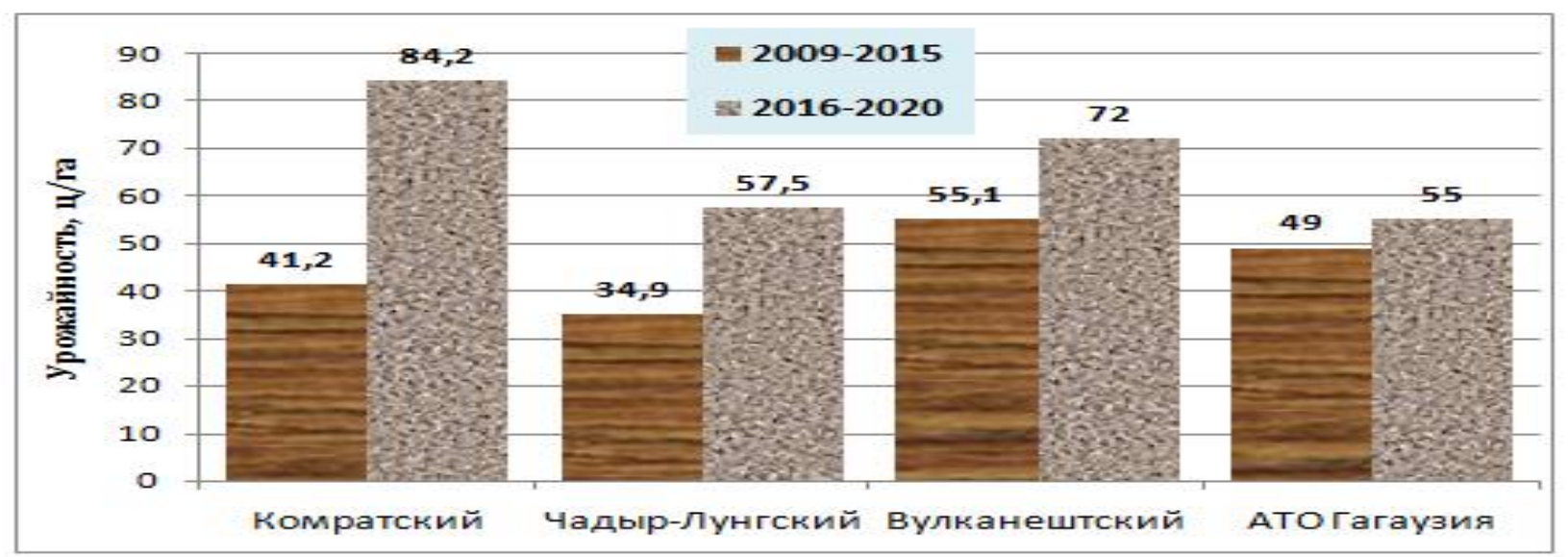

Рис.8. Показатели урожайности винограда в Комратском, Чадыр-Лунгском и Вулканештском районах в среднем за 2009-2015 и 2016-2020 годы

Источник: выполнено по данным таблицы 2 
Анализ стабильности производства. В ходе исследования важно провести анализ стабильности (устойчивости) производства винограда за исследуемый период. С этой целью следует выявить среднегодовой показатель, сложившиеся отклонения за годы анализа. Отношение отклонений к среднегодовому показателю указывает на стабильность. Обычно определяют коэффициент вариации в процентах. Важно также показать размах вариации- разницу между максимальными и минимальными показателями.

Сложившиеся показатели стабильности производства винограда в анализируемых хозяйствах представлены в таблице 3.

Приведенные данные свидетельствуют об огромной разнице между максимальными и минимальными значениями показателей, т.е. размах вариации достигал значительных размеров. Так, в среднем за исследуемые 24 года отношение размаха вариации площади уборки к среднегодовому показателю составил 129,0\%, валового сбора 124,5\%, урожайности 202,1\%. Принято считать, что если коэффициент вариации превышает 20\%, то производство считается не стабильным. Для отрасли сельского хозяйства это означает, что производство сосредоточено в зонах неустойчивого (рискованного) земледелия. Следовательно, производство винограда характеризуется низкой стабильностью.

В экономике с целью установления более объективных среднегодовых показателей производства используется метод среднегодовой скользящей. Его сущность состоит в том, что проводится анализ показателей не только на основе годовых значений, но и среднегодовых показателей, например, в среднем за последние 3-5 лет. Этот метод позволяет сглаживать показатели, нивелируя таким образом, в частности, негативное влияние погодноклиматических условий на результаты производства.

Таблица 3. Показатели устойчивости производства винограда в сельскохозяйственных предприятиях АТО Гагаузия за 1997-2020 годы

\begin{tabular}{|c|c|c|c|}
\hline Наименование показателей & $\begin{array}{c}\text { Площадь уборки, } \\
\text { га }\end{array}$ & $\begin{array}{c}\text { Валовой сбор, } \\
\text { т }\end{array}$ & $\begin{array}{c}\text { Урожайность, } \\
\text { ц/га } \\
\end{array}$ \\
\hline \multicolumn{4}{|c|}{ В среднем за 1997-2020 } \\
\hline В среднем за год & 9301 & 34905 & 37,5 \\
\hline $\begin{array}{c}\text { Среднегодовые стандартные } \\
\text { отклонения }\end{array}$ & 4030 & 10978 & 22,2 \\
\hline Коэффициент вариации, \% & 43,3 & 31,5 & 59,2 \\
\hline Размах вариации & 11996 & 43441 & 75,8 \\
\hline \multicolumn{4}{|c|}{ В среднем за 1997-2008 } \\
\hline В среднем за год & 12891 & 38332 & 29,7 \\
\hline $\begin{array}{l}\text { Среднегодовые стандартные } \\
\text { отклонения }\end{array}$ & 2020 & 10240 & 9 \\
\hline Коэффициент вариации, \% & 15,7 & 26,7 & 31,0 \\
\hline Размах вариации & 7629 & 33082 & 26,7 \\
\hline \multicolumn{4}{|c|}{ В среднем за 2009-2020 } \\
\hline В среднем за год & 5711 & 31477 & 55,1 \\
\hline $\begin{array}{c}\text { Среднегодовые стандартные } \\
\text { отклонения }\end{array}$ & 1326 & 11022 & 23 \\
\hline Коэффициент вариации, \% & 23,2 & 35,0 & 41,9 \\
\hline Размах вариации & 3422 & 39754 & 75,8 \\
\hline
\end{tabular}

В сельском хозяйстве возможны случаи низкой урожайности возделываемых культур, что может привести к убыточности реализованной продукции. Однако, это не означает, что возделывание данной культуры следует прекратить. В последующие годы эффективность товарной продукции может обеспечить высокую рентабельность, которая перекроет убытки минувшего года. Вот почему важно использовать метод среднегодовой скользящей, при котором рассчитываются показатели эффективности не только за истекший год, но и за последние 3-5 лет.

В подтверждение вышеизложенного проведем расчеты показателей площади уборки, валового сбора и урожайности винограда, методом среднегодовой скользящей. Результаты расчетов приводятся в таблице 4. Нами выбраны 4-летние среднегодовые скользящие.

Таблица 4. Годовые и среднегодовые показатели производства озимой пшеницы в сельскохозяйственных предприятиях АТО Гагаузия за 1997-2020 годы

\begin{tabular}{|l|l|l|l|l|l|l|}
\hline Год & \multicolumn{2}{l}{$\begin{array}{l}\text { Плодоносящая } \\
\text { площадь, га }\end{array}$} & \multicolumn{2}{l|}{ Валовой сбор, } \\
\cline { 2 - 6 } & за год & $\begin{array}{l}\text { за последние } \\
\text { 4 года }\end{array}$ & за год & $\begin{array}{l}\text { за } \\
\text { последние }\end{array}$ & за год & $\begin{array}{l}\text { за } \\
\text { последние }\end{array}$ \\
\hline
\end{tabular}




\begin{tabular}{|c|c|c|c|c|c|c|}
\hline & & & & 4 года & & 4 года \\
\hline 1997 & 16816 & & 37089 & & 22,1 & \\
\hline 1998 & 15685 & & 29838 & & 19 & \\
\hline 1999 & 14914 & & 31535 & & 21,1 & \\
\hline 2000 & 12653 & 15017 & 53000 & 37866 & 41,9 & 25,2 \\
\hline 2001 & 12459 & 13928 & 33539 & 36978 & 26,9 & 26,5 \\
\hline 2002 & 12265 & 13073 & 46668 & 41186 & 38 & 31,5 \\
\hline 2003 & 11911 & 12322 & 44909 & 44529 & 37,7 & 36,1 \\
\hline 2004 & 12573 & 12302 & 57402 & 45630 & 45,7 & 37,1 \\
\hline 2005 & 12284 & 12258 & 40249 & 47307 & 32,8 & 38,6 \\
\hline 2006 & 12201 & 12242 & 29480 & 43010 & 24,2 & 35,1 \\
\hline 2007 & 11739 & 12199 & 24320 & 37863 & 20,7 & 31,0 \\
\hline 2008 & 9187 & 11353 & 31958 & 31502 & 34,8 & 27,7 \\
\hline 2009 & 8226 & 10338 & 26567 & 28081 & 32,3 & 27,2 \\
\hline 2010 & 8242 & 9349 & 13961 & 24202 & 16,9 & 25,9 \\
\hline 2011 & 5852 & 7877 & 25173 & 24415 & 42,2 & 31,0 \\
\hline 2012 & 5874 & 7049 & 21329 & 21758 & 36,2 & 30,9 \\
\hline 2013 & 4841 & 6202 & 36714 & 24294 & 85,8 & 39,2 \\
\hline 2014 & 4820 & 5347 & 32095 & 28828 & 66,6 & 53,9 \\
\hline 2015 & 4876 & 5103 & 28582 & 29680 & 58,6 & 58,2 \\
\hline 2016 & 4943 & 4870 & 33577 & 32742 & 67,7 & 67,2 \\
\hline 2017 & 4900 & 4885 & 39162 & 33354 & 79,9 & 68,3 \\
\hline 2018 & 4841 & 4890 & 53715 & 38759 & 92,7 & 79,3 \\
\hline 2019 & 6622 & 5327 & 44847 & 42825 & 67,7 & 80,4 \\
\hline 2020 & 4491 & 5214 & 21999 & 39931 & 49 & 76,6 \\
\hline В среднем & 9301 & 9102 & 34905 & 34987 & 37,5 & 38,4 \\
\hline Стандотклон. & 4030 & 3590 & 10978 & 7844 & 22,2 & 19,0 \\
\hline Коэффициент & 43,3 & 39,4 & 31,5 & 22,4 & 59,2 & 50,4 \\
вариации, \% & & & & & & \\
\hline Размах & 11996 & 10147 & 43441 & 25549 & 75,8 & 55,2 \\
вариации & & & & & & \\
\hline
\end{tabular}

Источник: выполнено по данным таблицьы 1

Данные таблицы 4 показывают, что с применением 4-летней среднегодовой скользящей, значения коэффициента вариации снижается при анализе показателей площадей уборки с 43,3 до $39,4 \%$ или на $1 / 10$, валового сбора - с 31,5 до $22,4 \%$ или на $2 / 5$, урожайности - с 59,2 до $50,4 \%$ или более чем на $1 / 6$. Разумеется, падают и значения размаха вариации. Так, разница между максимальным и минимальным значениями площадей снижается почти на $1 / 5$, валового сбора в 1,7 раза и урожайности почти в 1,2 раза. Динамика показателей годовых и среднегодовых показателей урожайности и валового сбора винограда представлена на рисунке 9 и 10. Из графика видно, коэффициент аппроксимации уравнения тренда возрос с 0,567 для годовых показателей урожайности до 0,874 для среднегодовых скользящих значений или более чем в 1,5 раза. Высокое значение коэффициента аппроксимации отмечается и при применении среднегодовой скользящей валового сбора винограда. Он возрос с 0,917 до 0,931 .

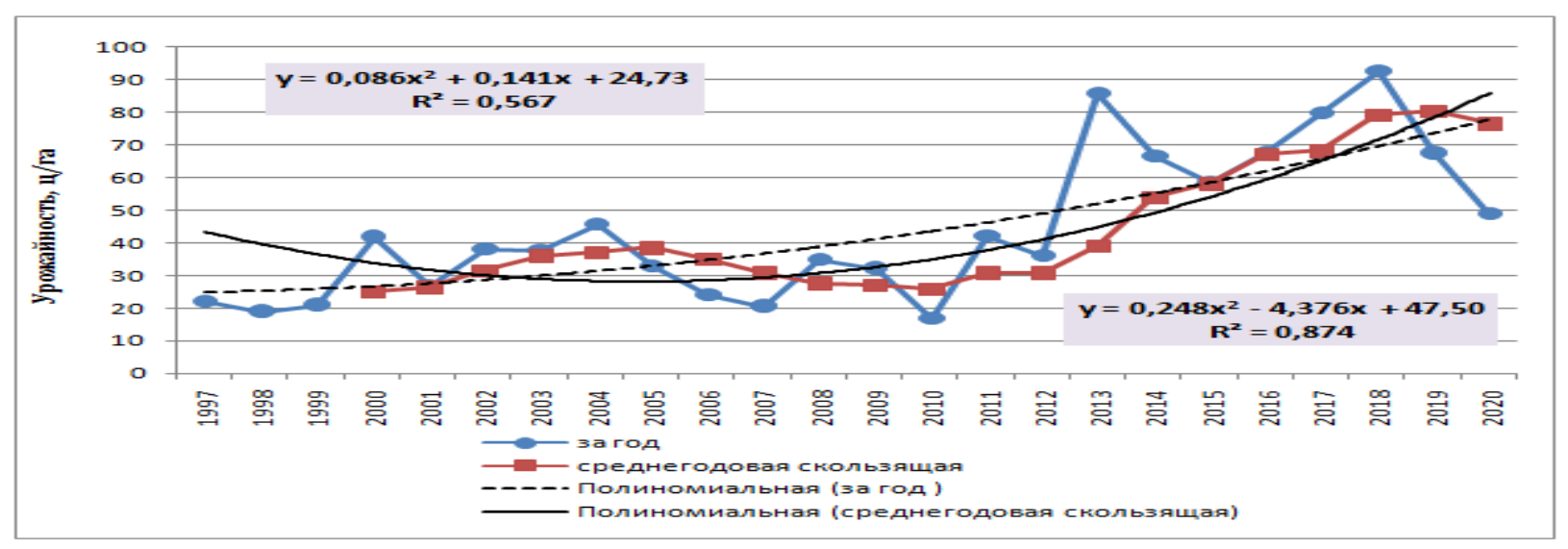

Рис.9. Динамика годовой и среднегодовой урожайности винограда в сельскохозяйственных предприятиях АТО Гагаузия за 1997-2020годы 


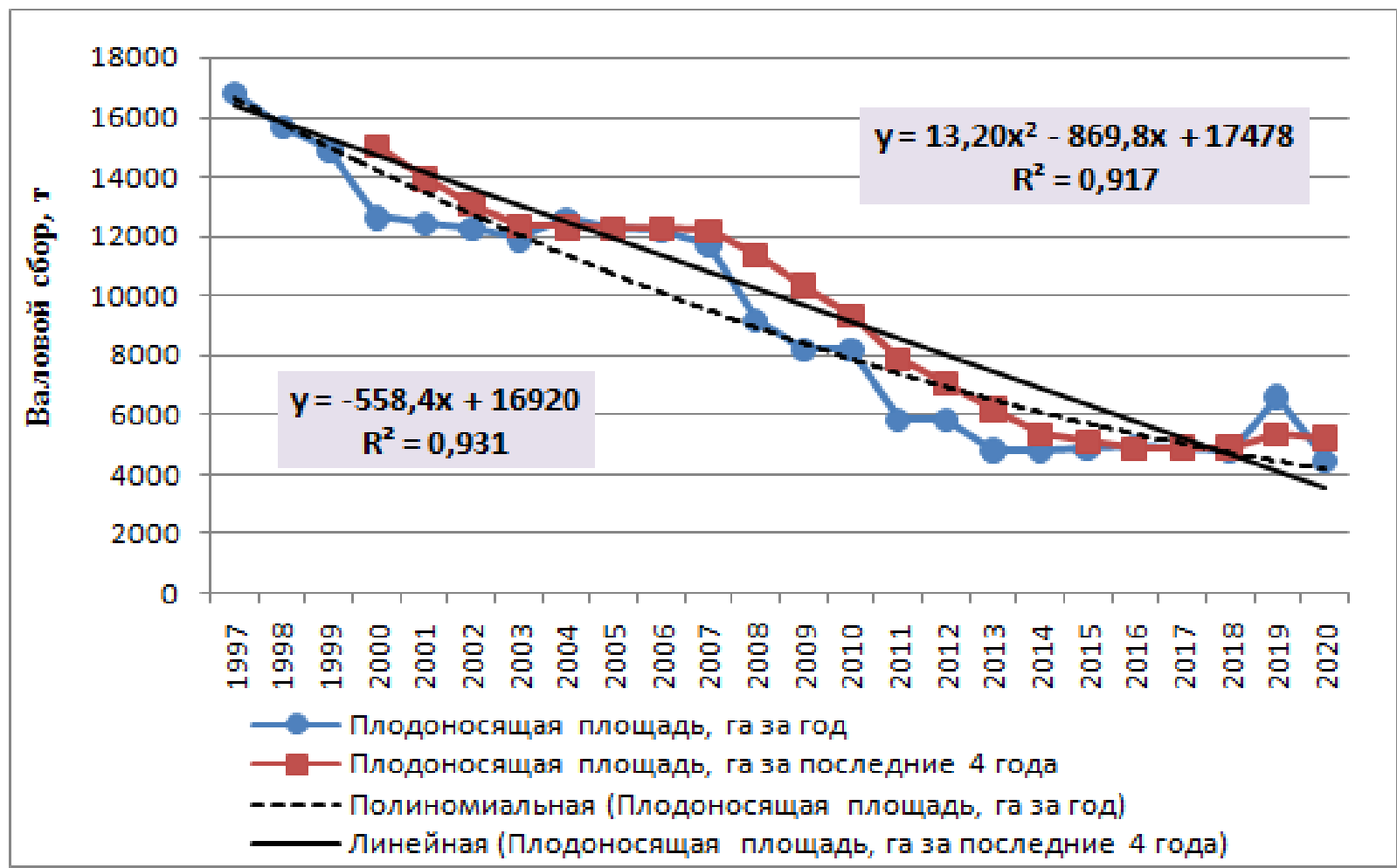

Рис.10. Динамика годовых и среднегодовых показателей производства винограда в сельскохозяйственных предприятиях АТО Гагаузия за 1997-2020 годы

Источник: выполнено по данным таблицы 4

В ходе проведения анализа были проведены расчеты темпов прироста (падения) площадей уборки, валового сбора и урожайности за исследуемые 24 года. В абсолютном исчислении в среднем за год прирост площадей уборки $\left(\Delta \mathrm{S}_{\mathrm{cp}}\right)$, находим по формуле:

$$
\Delta \mathrm{S}_{\mathrm{cp}}=\frac{\mathrm{S}_{\mathrm{K}}-\mathrm{S}_{\mathrm{H}}}{n-1}
$$

где: $\mathrm{S}_{\mathrm{K}}$ и $\mathrm{S}_{\mathrm{H}}$ - показатели площадей уборки соответственно конечного и начального периода; $\mathrm{n}$ - число лет в исследуемом периоде.

В относительной оценке прирост оценивается согласно выражения:

$$
\Delta S_{\text {ср }}^{\text {от }}=\sqrt[n-1]{\frac{S_{\mathrm{K}}}{\mathrm{S}_{\mathrm{H}}}}
$$

Падение площадей возделывания в соответствии с формулами 3 составил:

$$
\Delta S_{\mathrm{cp}}=\frac{4491-16816}{24-1}=-539,9 \text { га. }
$$

Снижение площадей по формуле 4 составит:

$$
\Delta S_{\mathrm{cp}}^{\mathrm{oT}}=\sqrt[n-1]{\frac{4491}{16816}}=0,9442
$$

Следовательно, с 1997 года по 2020 год в среднем за год плодоносящая площадь снижалась ежегодно почти на 540 га или на 5,6\%
Снижение произведенного винограда составило в среднем за год:

$$
\Delta Q_{\mathrm{cp}}=\frac{\mathrm{Q}_{\mathrm{K}}-\mathbf{Q}_{\mathrm{H}}}{n-1}=\frac{21999-37089}{24-1}=-656,1 \mathrm{~T}
$$

В соответствии с формулой 4:

$$
\Delta Q_{\mathrm{cp}}^{\mathrm{OT}}=\sqrt[n-1]{\frac{Q_{\mathrm{K}}}{\mathrm{q}_{\mathrm{H}}}}=\sqrt[n-1]{\frac{21999}{37089}}=0,9775
$$

Таким образом, производство янтарных гроздей ежегодно снижалось на 656 т или 2,2 \%.

Урожайность винограда к концу исследуемого периода претерпела существенное увеличение. Если в 1997 году с каждого гектара плодоносящей площади собрали по 22,1 ц, то к концу периода - уже 49,0 ц. В соответствии с формулой 3 рост в среднем за год составил 1,17 ц/га, а в относительной оценке $3,5 \%$ в год.

Прогноз показателей на 2021-2022 годы. Одним из наиболее простым, наглядным и доступным методом является графический метод прогнозирования при помощи анализа тренда в динамике за последние 5 и более лет.

Для того чтобы использовать графоаналитический метод прогнозирования, на графике следует показать два вида трендов: линейный и полиномиальный, а также уравнения и коэффициенты аппроксимации для каждого из них. Известно, что полиномиальный тренд лучше отражает тенденцию роста показателей, поскольку обладает более высоким коэффициентом аппроксимации. При данном тренде скачки 
показателя более сглажены, коэффициенты аппроксимации уже значительно выше, следовательно, уравнения более объективно отражают тенденцию, а значит, прогнозирование по данному графику будет более точным [4, с. 183-188].

Поскольку показатели по двум видам линии тренда (линейного и полиномиального) разнятся, принимаем в качестве прогнозных средние значения.

Таким образом, для прогнозирования показателей на последующие два года (2021 и 2022) используем как полиномиальный, так и линейный тренды.

Чтобы нивелировать в определенной степени влияние природных факторов на нестабильность производства, произведем расчеты прогнозных показателей методом нахождения средней скользящей. Для этого используем значения среднегодовых скользящих в среднем за 4 года, которые представлены в таблице 4.

На рисунке 11 представлена динамика среднегодовой скользящей урожайности винограда за исследуемый период с указанием двух вариантов тренда: линейного и полиномиального.

Выполним расчеты прогнозного значения урожайности по линейному тренду (уравнение тренда $\mathrm{y}=2,589 x+15,65)$ :

$$
\begin{gathered}
\text { урожайность в } 2021 \text { г: у }=2,589 * 22+15,65= \\
72,6 \text { ц/га } \\
\text { урожайность в } 2022 \text { г: у }=2,589 * 23+15,65= \\
75,2 \text { ц/га }
\end{gathered}
$$

Расчеты по уравнению полиномиальной линии тренда $(\mathrm{y}=0,249 * \mathrm{x} 2-2,888 * \mathrm{x}+36,65)$ :

$$
\begin{gathered}
\text { урожайность в } 2021 \text { г: у }=0,249 * 222-2,888 \\
* 22+36,65=93,6 \text { ц/га } \\
\text { урожайность в } 2020 \text { г: }: \mathbf{0}=\mathbf{0 , 2 4 9} * 232-2,888 \\
* 23+36,65=101,9 \text { ц/га }
\end{gathered}
$$

Таким образом, в среднем по прогнозу урожайность в 2021 году составит 86,1 ц/га:

$$
\begin{gathered}
(72,6+93,6) / 2=83,1 \text { ц/га, } \\
\text { а в } 2022 \text { году } 88,6 \text { ц/га: } \\
(75,2+101,9) / 2=88,6 ц / \text { га }
\end{gathered}
$$

Значения прогнозных показателей урожайности покажем для наглядности на графике (рис.12).

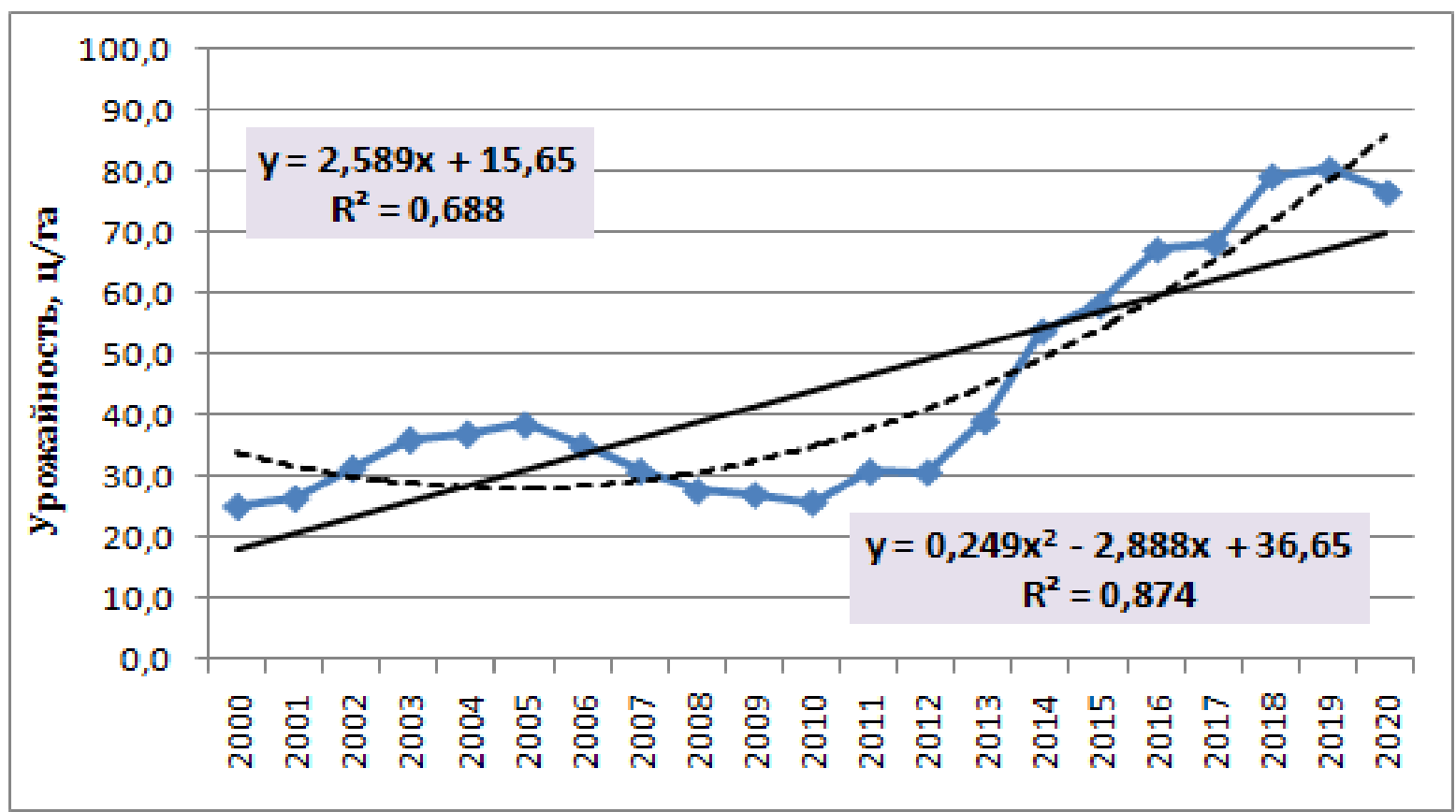

Рис.11. Динамика среднегодового (4-летнего) скользящего показателя урожайности винограда в сельскохозяйственных предприятиях АТО Гагаузия за 2000 - 2020 годы

Источник: выполнено по данным таблицы 4 


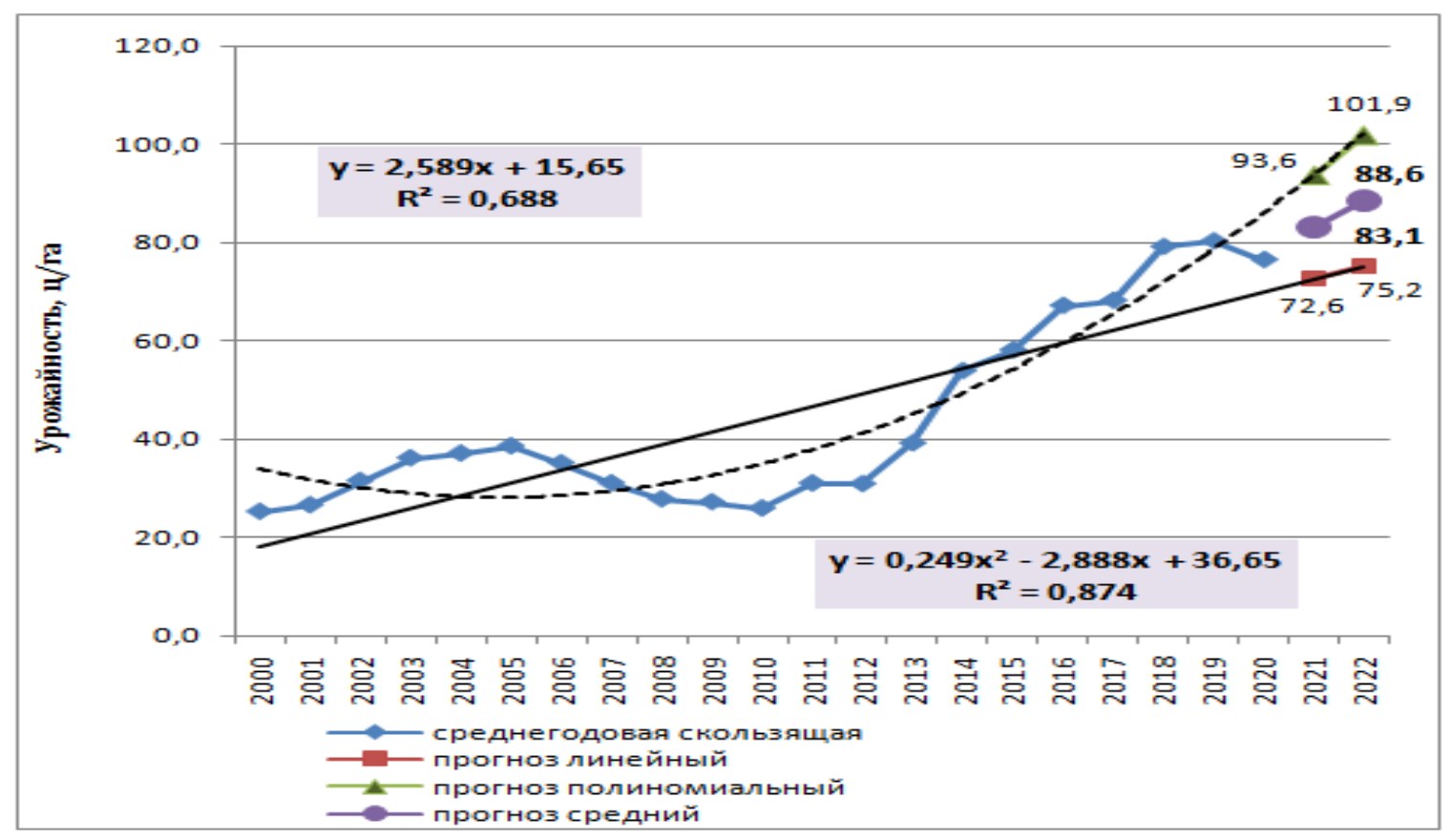

Рис.12. Показатели прогноза урожайности винограда в сельскохозяйственных

Источник: расчеты авторов предприятиях АТО Гагаузия на 2021 - 2022годы

В заключении отметим, что нами предложен один из вариантов проведения анализа состояния возделывания винограда в АТО Гагаузия, не претендуя на его приоритетность. Однако он является достаточно простым и доступным и потому может найти применение как у практикующих специалистов, так и студентов университетов.

\section{Библиографические сноски:}

1. Кара С.В. Развитие виноградарства технического направления в АТО Гагаузия. Conferința științificopractică internațională "Știința, educație, cultură”, USC, vol.1, Comrat, ISBN 978-9975-3246-7-0, 2019, p. 121-126.

2. Пармакли, Д.М. Эффективность использования земли в сельском хозяйстве АТО Гагаузия: теория и практика (монография), 2019. - 278 р.

3. Пармакли Д.М., Тодорич Л.П., Дудогло.Т.Д., Кураксина С.С., Яниогло А.И. Продуктивность земли в сельском хозяйстве. Монография6 под ред.Д.М.Пармакли; Комрат. Гос.ун-т, Н-и. центр «Прогресс».- Комрат, 2017 (Tipogr. "Centrografic"). - 242 p.

4. Пармакли Д.М. Экономические показатели деятельности предприятий. Учебное пособие, Комр. Гос. унив-т, Н-и. центр «Прогресс»-Комрат: Б.и.. 2019. (Tipogr- centrigrafic) -236 p. 